\title{
EVALUATION OF CHANGES IN BODY COMPOSITION AND EFFICENCY OF WOMEN UNDER THE INFLUENCE OF 4-MONTH STEP-AEROBICS TRAINING
}

\author{
OCENA ZMIAN SKŁADU CIAŁA ORAZ WYDOLNOŚCI KOBIET \\ POD WPŁYWEM 4-MIESIĘCZNEGO TRENINGU STEP AEROBIK
}

\author{
${ }^{12}$ Faculty of Physical Education, Kazimierz Wielki University Bydgoszcz, Poland \\ ${ }^{3}$ Department of Biochemistry Nicolaus Copernicus University in Toruń, Collegium Medicum in Bydgoszcz, Poland
}

\begin{abstract}
S u m mary
The aim of the study was to determine changes in body composition and efficiency of a group of women subjected to 4-month step-aerobics training. Issues of the research have been defined by the question: Were the body composition and efficiency of the researched women changed under the influence of step-aerobics, and if so, how big those changes were?

The study group consisted of 30 women aged 23-38 years, regularly attending the fitness classes of step-aerobics three times a week, lasting 45 minutes. Based on the measurements of height and weight BMI was calculated. Body composition was determined using the analyser TANITA. Cooper test was also conducted. Its purpose was to

VO2max), which is a determinant of physical condition. Based on the analysis of the results, the following conclusions were drawn: 1 .Step-aerobic has a positive effect on the body composition. The period of four-month training with frequency of 3 times a week caused: body weight loss by $3.86 \%$, decrease of BMI values on average by $3.83 \%$, reduction of the body fat levels on average by $17.75 \%$, increase of muscles mass on average by $2.21 \%$. 2 . Participation in class step-aerobics brings significant benefits associated with the level of efficiency. The period of fourmonth training with a frequency of 3 times a week caused an increase of women efficiency participating in this form of female fitness, on average by $17.31 \%$ (Cooper test results).
\end{abstract} determine the maximum aerobic capacity (i.e. Oxygen uptake

\section{Streszczenie}

Celem pracy było określenie zmian składu ciała oraz wydolności grupy kobiet poddanych 4-miesięcznemu treningowi step aerobik. Problematykę badawczą zdefiniowano w formie brzmiącego pytania: Czy skład ciała oraz wydolność badanych kobiet pod wpływem zajęć step aerobiku uległy zmianie, a jeśli tak to jak duże nastąpiły zmiany? Grupę badawczą stanowiło 30 kobiet w wieku od 23-38 lat, regularnie uczęszczających do klubu fitness na zajęcia step aerobiku trzy razy w tygodniu, trwające po 45 minut. Dokonano pomiaru wysokości i masy ciała badanych a na ich podstawie obliczono wskaźnik BMI. Skład ciała określono za pomocą analizatora TANITA. Przeprowadzono również test Cooper'a celem którego było określenie maksymalnej wydolności tlenowej (tzw. pułap tlenowy
$\mathrm{VO}_{2} \mathrm{max}$ ), stanowiący wyznacznik kondycji fizycznej. Na podstawie analizy uzyskanych wyników sformułowano następujące wnioski: 1) Step aerobik korzystnie wpływa na zmiany składu ciała. Uczestnictwo w tej formie fitness przez okres czterech miesięcy z częstotliwością 3-razy w tygodniu powodował u kobiet: spadek masy ciała średnio o 3,86\%, obniżenie wartości BMI średnio o 3,83\%, zmniejszenie poziomu tkanki tłuszczowej średnio o $17,75 \%$ wzrost masy mięśniowej średnio o 2,22\%. 2) Uczestnictwo w zajęciach step aerobiku przynosi znaczące korzyści związane $\mathrm{Z}$ poziomem wydolności. Okres czteromiesięcznego treningu $\mathrm{z}$ częstotliwością 3-razy w tygodniu powodował wzrost wydolności u uczestniczących w tej formie fitness kobiet średnio o 17,31\% (wyniki testu Cooper'a).

Key words: physical condition, step aerobics, women, body composition, efficiency, health

Słowa kluczowe: aktywność fizyczna, step aerobik, kobiety, skład ciała, wydolność, zdrowie 


\section{INTRODUCTION}

Despite longer life expectancy, the state of our society's health is unsatisfactory and the problem of diseases of civilization prevention with physical activity among children and adults has been discussed by doctors, psychologists, pedagogues, teachers and trainers.

The lack of proper physical activity, ensuring the health status, is the phenomenon affecting all societies worldwide. Fast development of modern civilization leads to systematic limitation of human's physical efforts causing lower physical activity.

During times when most of work is done in a seating position, people are threatened with many diseases caused by the lack of movement [1, 2] (overweight, failure of the cardiovascular system, poor metabolism and other body dysfunctions) $[3,4,5]$.

The concern for maintaining physical activity is important at any stage [6]. As Bar-Or [7] points out, child's activeness is a sign of proper development and for the elderly it prevents senility used by the aging process.

Good physical fitness is very desirable during whole life. Not only does it enrich and develop biological values of the body $[8,9,10]$ and facilitates professional activities but also influences its quality. Last decades at the turn of the XX and XXI century provide more prove that physical activity stimulates specific health benefits, supports somatic development, delays aging and prevents serious diseases and premature death. It results from available surveys (Schnohr 2006 Młynarczyk [11]) that people who perform appropriate dose of exercises (non-smoking with proper body mass) live 5 to 7 years longer than their peers who do not apply to the rules of healthy lifestyle.

According to the statistics, despite obvious benefits of physical activity, men and women participation in recreational activities is low [1, 12] and women exercise less than men $[9,13,14]$.

The care of the preservation of proper physical activity is important at all stages [6]. As Bar-Or points out, child's activeness is a sign of proper development and for the elderly it prevents senility as a result of aging. Due to low physical activity, diseases of civilization also affect children at school age. Study conducted by National Growth and Health Study (NGHS) indicates that physical activity level of children aged 9-19 has dropped dramatically over the last years [15]. The results of the study [16, 17, 18] prove that the lack of physical activity has significant influence on level of body fat and child's kinaesthetic activation influences not only motor development but also the other areas of development and functioning of the organism. Physical activity is beneficial for metabolic and hormonal mechanisms of a growing body. It modifies other health behaviours of healthimproving life style such as: change of eating habits, stress handling skills, drug avoidance [19]. Positive influence of physical activity on human body in old age and successful aging should not be underestimated. Regular, carefully chosen physical activity allows better self-control and independence, improves mood and quality of life in an advance age. It is undeniable that there are indication, which determine physical activity as a medicine of XXI century. Numerous WHO (World Health Organization) reports, international scientific societies and scientific publication still indicate that a sedentary lifestyle is one of the most serious health problems of modern person [11]. Efficient ways of persuading adults, children and teenagers to the purposefulness of properly targeted physical activity are worth finding.

\section{MATERIAL AND METHODS}

Material

Study group consisted of 30 women aged 23-38 years (13 women in the age group 18 to 24,8 women in the age group 25 to 31 and 9 women in the age group 31 to 38 ), regularly attending the fitness classes of step-aerobics three times a week, lasting 45 minutes. The youngest participant was 18 and the oldest was 38 .

\section{Methods}

Height and weight was measured /B-V/ and on their basis BMI was calculated according to the formula [20]:

$\mathrm{BMI}=\frac{\text { weight }[\mathrm{kg}]}{\text { height }\left[\mathrm{m}^{2}\right]}$

Using the analyser TANITA, which is based on bioelectrical impedance analysis, body composition was determined. A small current was passed through test subjects' bodies. Due to different reaction of individual tissues in human body (muscles, thanks to 
high content of water and electrolytes dissolved in it, provide good conductivity; the higher the water content and electrolytes dissolved in it, the lower the resistance is) determining the composition of respondents bodies was possible. The percentage of body fat was calculated with the use of the formula regarding resistance value, age, gender and height.

Cooper test was also conducted. Its purpose was to determine the maximum aerobic capacity (i.e. Oxygen uptake VO2max), which is a determinant of physical condition and is carried out as a continuous 12-minute run. Determination of the capacity is calculated on the basis of the length of a distance made in 12 minutes and then, depending on age and gender, compared to standardized operating classification.

The period of the study lasted 4 months and it was based on three-time measurement of the same indexes within the same group of women in two-month intervals between the measurements. Body mass and composition measurements were made on an empty stomach in the morning. Cooper test was conducted on the following day after a warm up. Study results were processed statistically [22].

\section{RESULTS}

Table I. Numerical characteristics of weight and height of the body, and BMI of the women involved in step aerobics (Source: own research)

\begin{tabular}{|c|c|c|c|c|c|}
\hline Research & Body features & $\mathrm{M}$ & Min-max & $\mathrm{V}[\%]$ & $\sigma$ \\
\hline I research & Body Mass [kg] & 65.21 & $54.1-93.2$ & 15.55 & 10.14 \\
\cline { 2 - 6 } & Body Height [cm] & 168 & $159-179$ & 3.16 & 0.05 \\
\cline { 2 - 6 } & Body Mass Index & 22.97 & $19.63-29.09$ & 11.42 & 2.62 \\
\hline \multirow{4}{*}{ II research } & Body Mass [kg] & 64.08 & $54.8-91.8$ & 14.69 & 9.41 \\
\cline { 2 - 6 } & Body Mass Index & 22.58 & $19.4-28.65$ & 10.78 & 2.43 \\
\hline $\begin{array}{c}\text { III } \\
\text { research }\end{array}$ & Body Mass [kg] & 62.69 & $54-94.4$ & 16.31 & 10.22 \\
\cline { 2 - 6 } & Body Mass Index & 22.09 & $18.69-29.46$ & 12.42 & 2.74 \\
\hline
\end{tabular}

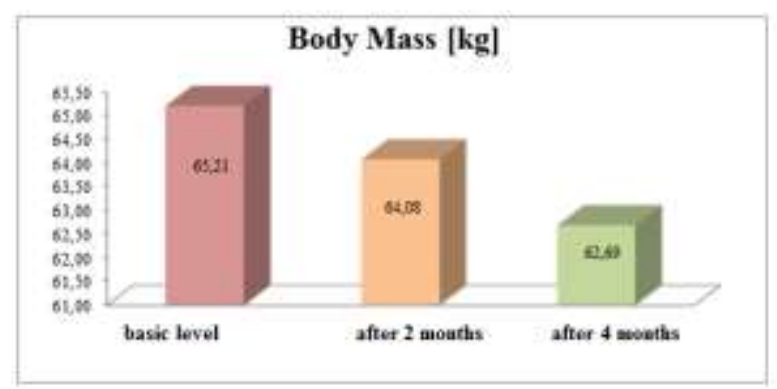

Fig. 1. The dynamics of changes in average body weight [kg] in body composition of women training step-aerobics after the 2-month period of training (Source: own research)
An average body weight loss for women taking up step-aerobic training after a two-month period was $1.13 \mathrm{~kg}(1.73 \%)$ and $1.39 \mathrm{~kg}$ after next period (Fig.1). In a four-month period an average body weight loss of the surveyed was noted to be 2.52 kilograms (3.86\%).

During 4-month physical activity called stepaerobic, eleven people lost from $3.5 \mathrm{~kg}$ to $10.7 \mathrm{~kg}$. Ten participants decreased their body mass not more than $3.5 \mathrm{~kg}$ and 8 women gained weight. It can be concluded that the lack of a balanced diet accompanying physical activity prevented achieving effective changes.

Average Body Mass Index value for the study group of women after the first measurement was 22.97 - it was within the norm according to World Health Organization. After a two-month training, tested women have decreased their BMI by 0.39 (1.70\%). Third measurement indicated decreasing tendency of BMI by $0.49(2.13 \%)$ - which during the period considered, was a drop of $0.88(3.83 \%)$ - Fig.2.

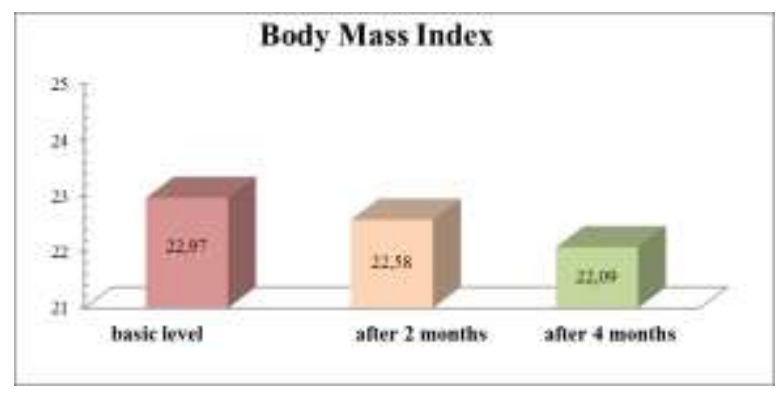

Fig. 2. Dynamics of changes in the average BMI of the women involved in step-aerobics after a 2-month period of training (Source: own research)

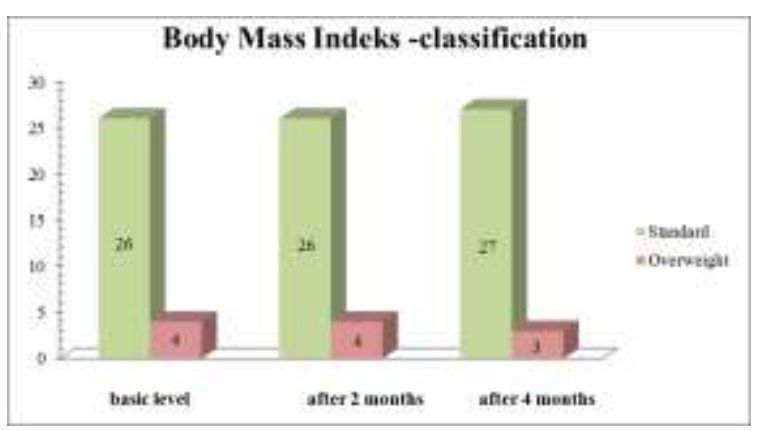

Fig. 3. Individual analysis of the BMI classification of women training step-aerobics after a 2-month period of training (Source: own research)

Most of the women, 26 (73\% of the study group), according to available classification, was characterized by BMI within the norm. Only four of them were overweight. It has not changed after the next two months of practicing step-aerobic. Only after a fourmonth period of training (third measurement) one of 
the women's weight decreased putting her within the norm (Fig. 3).

Table II. Numerical characteristics of the fat share in body composition of women training step-aerobics (Source: own research)

\begin{tabular}{|l|c|c|c|c|}
\hline Body Fat & M [\%] & $\begin{array}{c}\text { Min-max } \\
{[\%]}\end{array}$ & V [\%] & $\Sigma$ \\
\hline I research & 24.48 & $19.9-28.2$ & 9.89 & 2.42 \\
\hline II research & 22.61 & $18.6-26.9$ & 9.86 & 2.23 \\
\hline III research & 21.90 & $16.97-25.3$ & 10.12 & 2.22 \\
\hline
\end{tabular}

One of the most significant controlled indicators was body fat, which during the first measurement was almost $25 \%$ of the whole body for the tested group of women (Tab. II). After the two-month period of training - during the second measurement, body fat loss was noted by $1.87 \%$, and by $0.71 \%$ during the next one. After a four-month period of the study, a drop in body fat by $2.58 \%$ was noted (Fig. 4 ).

Fig. 4. Dynamics of the average values of body fat share

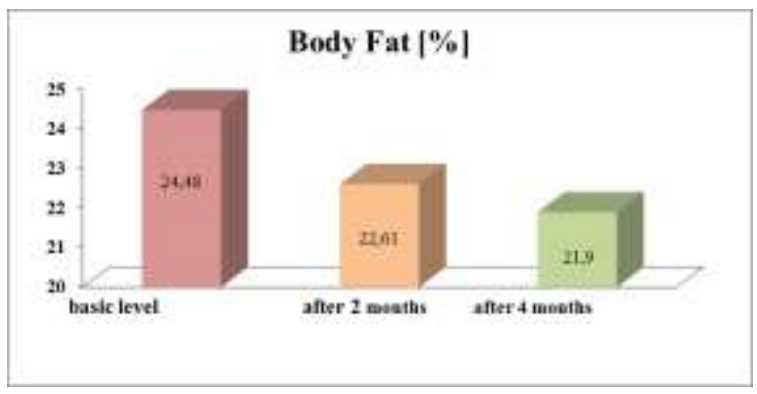

changes [\%] in body composition of women training step-aerobics after 2-month period, (Source: own research

Table III. Numerical characteristics of muscular mass share in body composition of women training stepaerobics (Source: own research)

\begin{tabular}{|l|c|c|c|c|}
\hline Muscular Mass & $\mathrm{M}[\mathrm{kg}]$ & $\min .-\max [\mathrm{kg}]$ & $\mathrm{v}[\%]$ & $\Sigma$ \\
\hline I research & 47.75 & $39.1-70.04$ & 18.63 & 8.90 \\
\hline II research & 48.08 & $39.3-71.4$ & 15.60 & 7.50 \\
\hline III research & 48.81 & $40.8-78.3$ & 17.15 & 8.37 \\
\hline
\end{tabular}

The biggest changes in muscle content similarly to the previous parameters measurements, were noted in the third measurement (Tab. III). Between the first and the second measurement, average gain in muscle size was $0.25 \mathrm{~kg}(0.52 \%)$, which did not differ much in comparison to a two-month period of regular training. With the last measurement the value increased by $0.81 \mathrm{~kg}(1.69 \%)$ from previous measurement, which could be a result of the increased intensity of the training caused by the progress of the training group and more aware participation in that training (the increase of muscle memory, better knowledge of choreography elements).

Oxygen nature of the step-aerobic training should also be considered. It leans toward body fat reduction rather than building muscles. During a four-month period of training, a group of studied women increased their body muscles by $1.06 \mathrm{~kg}(2.21 \%)$ - Fig. 5 .

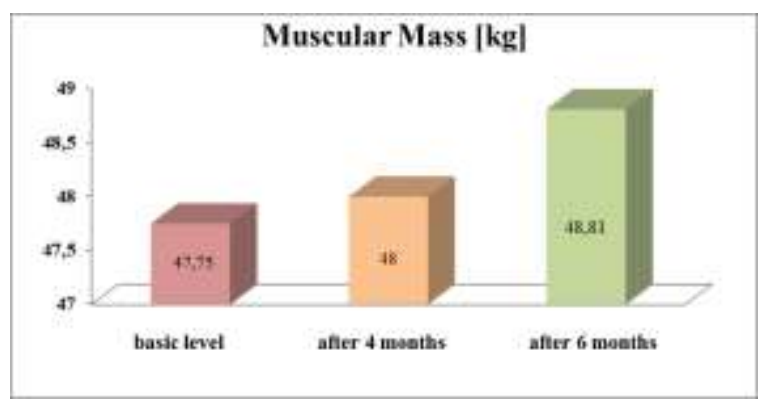

Fig. 5. Dynamics of changes in the average value of the muscular mass share [kg] in body composition of women training step-aerobics after a 2-month period (Source: own research)

Studied group of women participated in the Cooper test allowing the assessment of step aerobics influence on efficiency levels changes (Tab. IV).

Table IV. Numerical characteristics of the Cooper test results in subsequent studies (Source: own research)

\begin{tabular}{|l|c|c|c|c|}
\hline Cooper's Test & M [m] & Min-max [m] & $\begin{array}{c}\text { V } \\
{[\%]}\end{array}$ & $\Sigma$ \\
\hline I research & 1788.33 & $1200-2600 \mathrm{~m}$ & 18.44 & 329.82 \\
\hline II research & 1963.33 & $1400-2800 \mathrm{~m}$ & 17.13 & 336.39 \\
\hline III research & 2101.67 & $1450-3050 \mathrm{~m}$ & 16.60 & 348.92 \\
\hline
\end{tabular}

During the first test over a half of women (16 participants) did not indicate enough level of efficiency and failed to cover a distance of 1800 meters in 12 minutes. During the analysis of the second measurement almost the same number of women (14 participants) could then be assigned to the group with the average endurance. Two of women from the average group improved their result which qualified them in the group with a good result. The last measurement indicated that $13 \%$ of participant during the whole period of the study failed to achieve the result on an average level (Fig.6). 
Fig. 6. Dynamics of changes in strength (Cooper's test), of women training step-aerobics after a 2-month period (Source: own research)

Each time the analysis of the test results in

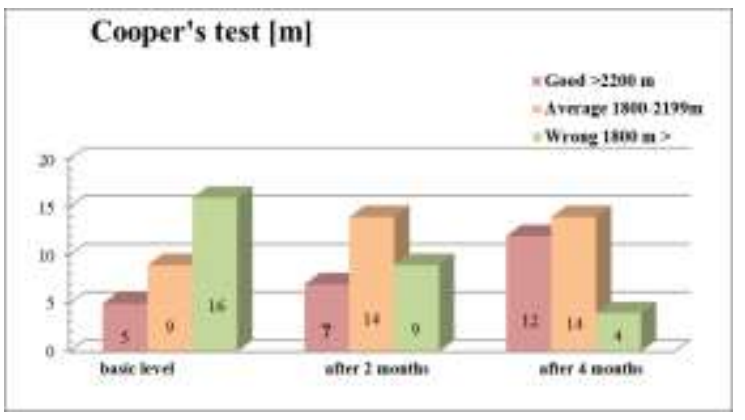

subsequent research efficiency of the women practicing step-aerobic showed an increase in values. It is obvious that regular physical activity of an oxygen nature had a significant influence on the results achieved during the four-month period of study, indicating growing trend. The biggest total distance growth was observed during the second measurement and it was longer by 175 meters than the average initial measurement. The last research also indicated average growing trend (by $138.34 \mathrm{~m}$ ) and together with the previous measurement result it was 313.34 meters, which is a satisfactory result for the study group (Fig.5). Most of the participants declared that their mood improved significantly with the start of stepaerobic training.

\section{CONCLUSION}

On the basis of analysis of results achieved in the study the following conclusions were reached:

1. Step-aerobic has a positive effect on the body composition. The period of four-month training with frequency of 3 times a week caused:

- body weight loss by $3.86 \%$,

- decrease of BMI values on average by $3.83 \%$,

- reduction of the body fat levels on average by $17.75 \%$,

- increase of muscles mass on average by $2.21 \%$.

2. Participation in step-aerobics brings significant benefits associated with the level of efficiency. The period of four-month training with a frequency of 3 times a week caused the increase of women efficiency participating in this form of female fitness, on average by $17.31 \%$ (Cooper test results).

\section{REFERENCES}

1. Erdman L. Miejsce rekreacji fizycznej w sposobach życia ludności. [W:] II Kongres Naukowy Kultury Fizycznej - 9 - Materiały i Dokumenty. Warszawa 1987.

2. Ziemiański S. Człowiek i środowisko. Rola żywienia i wysiłku fizycznego w profilaktyce chorób cywilizacyjnych. Kultura Fizyczna, 1992, 1-2, 9-11.

3. Bejnarowicz J. Zmiany stanu zdrowia Polaków i jego uwarunkowań. Wyzwania dla promocji zdrowia. Promocja zdrowia. Nauki Społeczne i Medycyna, 1994, 1-2, 9-36.

4. Cendrowski Z. Życie i zdrowie największym bogactwem narodu - powszechna aktywność fizyczna największą szansą ich urzeczywistnienia. Lider, 1994, 3:4-5.

5. Romanowski W., Eberhard A. Profilaktyczne znaczenie zwiększonej aktywności ruchowej człowieka. Warszawa 1972, PZWL.

6. Jopkiewicz A. Biologiczne podstawy rozwoju człowieka. WSP, Kielce 1998, 122-128.

7. Bar-Or O. Pediatric Sports Medicine for the Practioner, New York. Springer - Verlag. 1983.

8. Kozłowski S. Znaczenie aktywności ruchowej w rozwoju fizycznym człowieka. [W:] Wolański N. (red): Czynniki rozwoju człowieka. Warszawa 1981, PWN.

9. Kosko J. Aktywność fizyczna a zdrowie. [W:] Gniazdowski A. (red): Zachowania zdrowotne. IMP Łódź, 1990

10. Starosta W. Znaczenie aktywności ruchowej w zachowaniu i polepszaniu zdrowia człowieka. Promocja zdrowia. Nauki Społeczne i Medycyna. 1995, 5-6.

11. Młynarczyk I. Potęga ruchu. Potęga zdrowia. Kwartalnik Śląskiego Centrum Chorób Serca nr 18. SCCN 2010: 6-8. ISSN 1730-1297.

12. Nowak M., Wojtas-Ślubowska D. Społecznoekonomiczne uwarunkowania uczestnictwa kobiet w rekreacji fizycznej. [W:] Turystyka, rekreacja i sport jako problem społeczno-wychowawczy współczesnego człowieka. Red. W. Siwiński, Poznań 1993, 132-136.

13. Gawlak-Kica G. Uczestnictwo w kulturze fizycznej mieszkańców makroregionu środkowo-zachodniego. Roczniki Naukowe AWF w Poznaniu, Poznań 1992, 31:159-171.

14. Kunicki B.J. Społeczne bariery rekreacji fizycznej. AWF Warszawa 1984.

15. Kimm S.Y.S. Glynn, N.W., Kriska A. iwsp. Longitudinal assessment of physical activity from childhood through adolescence. Med. Sci. Sports. Exerc., 1999, 32, 1445-1454.

16. Fogelholm M. Effects of bodyweight reduction on sports performance. Sports Med., 1994, 18, 249-267.

17. Janssen I., Kaczmarzyk P.T., Boyce W.F., King M., Pickett W. Overweight and obesity in Canadian adolescents and their associations with dietary habits and physical activity patterns. J. Adolesc. Health, 2004, $35,360-367$. 
18. Klesges R.C., Klesges L.M., Eck L.H., Shelton M.L. A longitudinal analysis of accelerated weight gain in preschool children. Pediatrics, 1995, 1, 126-130.

19. Grodzka-Kubiak E. Aerobik czy fitness, Maestro, Poznań 2002.

20. Charzewski J. (red.) Antropologia. Wydanie I, Wydawnictwo Akademii Wychowania Fizycznego, Warszawa 1999.

21. Cooper K.H.. A means of assessing maximal oxygen uptake. Journal of the American Medical Association 1968.

22. Arska-Kotlińska M., Bartz M., Wieleński D. Wybrane zagadnienia statystyki dla studiujących wychowanie fizyczne. Wydanie III zmienione i uzupełnione, Wydawnictwo Akademii Wychowania Fizycznego, Poznań 2002.
Address for correspondence:

Wiesława Pilewska

e-mail: wikapi@vp.pl mobile phone:+48500093450

Malwina Skowrońska

e-mail: malwa12345@onet.eu

mobile phone:+48880833579, 880833579

Beata Augustyńska

e-mail: augustynska@op.pl

Received: 20.07.2016

Accepted for publication: 12.08.2016 